\title{
Jet Propulsion Laboratory is considering its options
}

\section{Pasadena}

THE summer of 1989 will be a busy time for the Jet Propulsion Laboratory (JPL) in Pasadena, if everything goes according to plan. Magellan, the Venus radar mapper, will be on its way, Voyager will make the first-ever encounter with Neptune, and Galileo will be only months away from starting on its planetary billiard shot that will eventually take it to Jupiter by way of Venus and Earth. Although those missions will keep planetary scientists busy for some years, JPL must find new projects to carry it through the next decade.

The loss of the space shuttle Challenger brought the US planetary science programme to an abrupt halt. Occurring just days after a fabulously successful encounter with Uranus by Voyager, the accident forced the further postponement of Galileo, a mission JPL has directed from its inception. Galileo was due to arrive at Jupiter later this year, but is now delayed until December 1995.

As NASA's primary centre for planetary science, JPL has been hard hit by Galileo's delays. It is more than 10 years since the United States last launched a mission to the planets. Although increased attention to Mars is high on Reagan's agenda for US space activities, apart from the Mars Observer probe to be launched in 1992, most Mars projects are only in the early development stage.

JPL occupies a unique position among NASA regional centres. Unlike all others, it is operated by an academic institution the California Institute of Technology - and its 5,300 employees work for Caltech, not the government. This gives JPL scientists flexibility their civil service colleagues lack. But it also means they must ask for more money when seeking grants from NASA, as personnel costs must be added into the budget, instead of being part of the institutional overhead.

Lew Allen, director of JPL, says the country is in danger of losing a valuable resource if JPL is not assigned a new planetary mission. The laboratory has a broad range of disciplines related to manufacturing spacecraft, and had planned to devote its future energies toward the Mariner Mark II spacecraft - designed for sophisticated planetary missions but not as comprehensive a spacecraft as Galileo. But it now seems that the Reagan administration will not give a go-ahead in the 1989 budget to the Comet Rendezvous, Asteroid Flyby (CRAF), the first planned Mariner Mark II mission. Without CRAF or Cassini, its sister mission to Saturn's moon Titan, JPL will have to shift direction in a hurry to find new ways to keep its spacecraft builders busy.
One possibility, according to Allen, is a sample return mission to Mars. A combination of events appears to be conspiring to make Mars the next object of intensive operation. Popular enthusiasm for the planet has always been high, and two reports on NASA's future have recommended trips to Mars as future goals of the agency. There is also the need to come up with something for the International Space Year, set for 1992. NASA will also be under pressure to keep up with the Soviet Union's ambitious Mars plans.

But Moustafa Chahine, chief scientist at JPL, believes it is a mistake to focus too much on Mars. Chahine says the next logical question for planetary scientists to

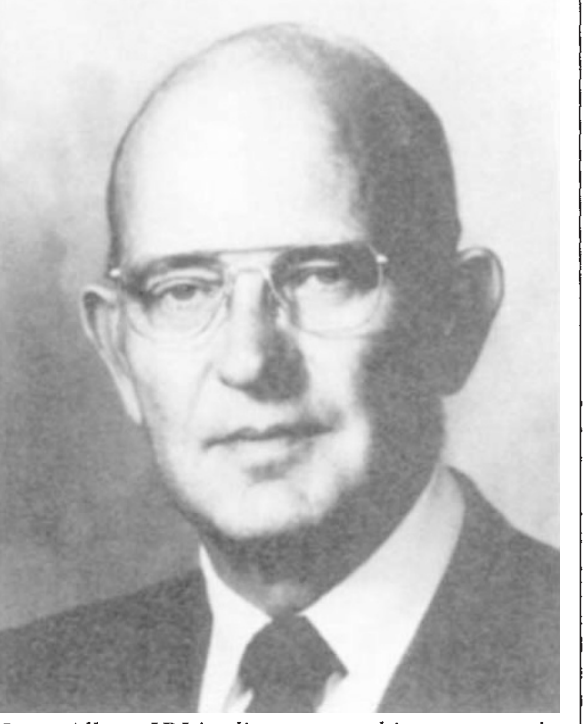

Lew Allen, JPL's director, making space missions popular.

study is the molecular and atomic evolution of the Solar System. That can be done only with a broad planetary programme aimed at more than one planet.

Despite the uncertain future and launch delays, Chahine says morale at JPL remains high. Enthusiasm for the redesigned Galileo mission is high, and although the new trajectory triples the time needed to reach Jupiter, there will be previously unplanned possibilities for scientific observations of Venus, Earth and two asteroids.

Chahine is also cheered by a new report being prepared for NASA administrator James Fletcher concluding that the quality of scientific research at NASA centres particularly JPL - is at least the equal of that in universities. But D. James Baker, author of the report, warns that without a strong commitment to planetary science in the future, JPL will be forced into new areas of research - most likely defencerelated work - to the detriment of the civilian space programme. Joseph Palca

\section{SmithKline cash for Cambridge}

\section{Tokyo}

A BRITISH attack on the human genome is to be launched by Dr Sydney Brenner with the help of the Medical Research Council (MRC), the Imperial Cancer Research Fund (ICRF) and SmithKline Beckman Corporation, the pharmaceutical company. The company is to give $\$ 2.25$ million to the School of Clinical Medicine of the University of Cambridge to which Brenner will move his MRC unit later this year.

For Brenner, the move represents the beginning of the end of a long struggle to find backing for a serious attempt to apply his technique for mapping the genome of the nematode worm Caenorhabditis to the much larger human genome.

Until the appointment of Dr Dai Rees as secretary of the MRC last October, the council had seemed reluctant to back Brenner's project and, although he had some other funds available, including his share of last year's Louis Jeantet Foundation prize, they were not enough. The problem has been solved by Brenner, Rees, Sir Walter Bodmer, ICRF's director, and Keith Peters, Regius Professor of Physics at the University of Cambridge.

Of SmithKline Beckman's contribution, $\$ 1$ million is to be spent on refurbishing and equipping laboratories at the School of Clinical Medicine and the rest on supporting research over the next five years. Officially, Brenner will advise Peters on the programme of research, with further advice from Dr Tim Rink, who left the department of physiology at Cambridge to become vice-president of research at the company's UK subsidary, Smith Kline French.

Molecular research into cardiovascular disease, virus infections and autoimmunity will receive priority. The company retains the option to patent and commercialize the outcome of its investment; royalties will accrue to the university.

Exactly how ICRF will contribute to Brenner's mapping efforts has yet to be worked out but is likely to take the form of a group of ICRF-supported scientists working alongside Brenner. There will be close links between the Cambridge scientists and the group of Drs Hans Lehrach and Anna-Marie Frischauf at the ICRF laboratory in London, which has already began work on human genome mapping.

The result, says Bodmer, should be a powerful and concerted programme of research on the human genome in Europe. Discussions on including other European partners, particularly in France, are under way. Another result, of particular importance to Brenner, is that the project can continue after he has been pensioned off by MRC. Peter Newmark 